\title{
Educação, poder e ordem: política e quotidiano numa escola de formação de professores
}

\author{
Education, power and order: \\ politics and daily life in a teacher training school
}

\author{
Luís MOTA ${ }^{1}$ \\ António Gomes FERREIRA²
}

\begin{abstract}
Resumo
Centrado na Escola do Magistério Primário de Coimbra (EMPC), entre 1942 e 1974, constitui um recorte de uma investigaçáo mais vasta sobre as instituiçóes públicas de formação de professores do ensino primário, em Coimbra, nos séculos XX e XXI. As fontes mobilizadas foram o arquivo, a memória e o museu onde analisámos dimensóes das áreas pedagógica e didática, bem como sociocultural. A partir da triangulação de dados construímos uma interpretação do modelo pedagógico da EMPC, polarizado nos conceitos de educação, poder e ordem, tendo como pano de fundo a relação dialética entre a norma e as práticas sociais.
\end{abstract}

Palavras-chave: Formação de professores. Escola do Magistério Primário. Estado Novo.

\begin{abstract}
The study focuses on a teachers training school in Coimbra (EMPC) between 1942 and 1974. It's a cut of a broader investigation into the public institutions of primary teachers education in Coimbra in the 20th and 21st centuries. The sources mobilized were the archive, the memory and the museum, where dimensions of the pedagogical and didactic areas were analyzed, as well as the sociocultural ones. From the triangulation of data we constructed an interpretation of the pedagogical model of the EMPC, polarized in the concepts of education, power and order, against the background of the dialectic relationship between norm and social practices.
\end{abstract}

Keywords: Teacher Training. Teachers Training School. New State.

1 Doutor em História da Cultura. Professor adjunto do Instituto Politécnico de Coimbra, na Escola Superior de Educação (IPC, ESE). Vice-coordenador científico do Grupo de Políticas e Organizaçôes Educativas e Dinâmicas Organizacionais, do Centro de Estudos Interdisciplinares do Século XX, da Universidade de Coimbra (GRUPOEDE, CEIS20, UC). Endereço institucional: R. Dom João III, 3030-329 Coimbra, Portugal. Tel.: 239793120 E-mail: <mudamseostempos@gmail.com>.

2 Doutor em Ciências da Educaçáo. Professor associado e diretor da Faculdade de Psicologia e de Ciências da Educação da Universidade de Coimbra (FPCEUC). Coordenador científico do Grupo de Políticas e Organizaçôes Educativas e Dinâmicas Organizacionais, do Centro de Estudos Interdisciplinares do Século XX, da Universidade de Coimbra (GRUPOEDE, CEIS20, UC). Endereço institucional: R. Colégio Novo, 3000-115 Coimbra, Portugal. Tel.: 239851450 E-mail:<antonio@fpce.uc.pt>.

R. Educ. Públ. v. 27

n. 66 p. $883-901$ set./dez. 2018 


\section{Introdução}

O presente estudo constitui um recorte e, em certa medida, uma reinterpretação, i. é, submeter os dados a um renovado inquérito. Focalizado numa instituição educativa, a Escola do Magistério Primário de Coimbra (EMPC), em Portugal, especialmente no período de 1942 a 1974, sendo um recorte de uma pesquisa mais vasta sobre as instituições públicas de formação de professores do ensino primário, em Coimbra, nos séculos XX e XXI. Para a análise de dimensóes das áreas pedagógica, didática e sociocultural da EMPC recorremos a fontes de arquivo, da memória e do museu (MAGALHÁES, 2004). Com recurso à análise de conteúdo e a partir da triangulação de dados construímos uma interpretação do modelo pedagógico da EMPC, polarizado nos conceitos de educaçáo, poder e ordem, tendo como pano de fundo a relação dialética entre a norma e as práticas sociais (AMADO, 2013).

A reinterpretação dos dados respalda-se em conceções sobre as instituiçóes educativas, o tipo de liderança de governação das escolas e a natureza e ação do Estado num dado momento histórico. As escolas, enquanto instituiçóes educativas, conservam um significativo grau de diferenciação entre si, mesmo entre instituiçóes congéneres contemporâneas, afirmando-se como meio de transmissão da cultura escolar, mas, de igual modo, produtoras de culturas e de identidades próprias. No caso vertente, a EMPC era uma realidade dentro de outra realidade, confrontada à escala nacional (e também internacional) por uma norma e uma estrutura educativa que se atualiza na relação dialética entre norma e estrutura e a liberdade e autonomia dos seus atores, sempre fiéis aos seus objetivos originando espaços para infidelidades normativas e construçóes identitárias (LIMA, 1998; MAGALHÂES, 2004; SANFELICE, 2009).

No quadro das instituiçóes, em geral, e das educativas, em particular, uma liderança forte e prestigiada pode permitir aos demais atores educativos desfrutarem de um certo grau de liberdade que resulta num investimento positivo no espaço escolar. O prestígio e uma liderança forte, num contexto de consenso alargado ao nível da ideologia e dos valores educativos, como era a situaçáo experienciada em Portugal durante o período do Estado Novo, cria condiçóes para o desenvolvimento de processos identitários de identificação com a instituição educativa. O exercício de um autoritarismo paternalista, por parte dos diretores das escolas do magistério, bem à imagem e semelhança de António de Oliveira Salazar, é propício ao aparecimento de "manifestaçóes concetuais e simbólicas e comportamentais que exprimem a adesão ao projeto institucional" (NÓVOA, 1992, p. 487). Neste contexto, podemos afirmar que a EMPC desenvolveu uma 
cultura integrativa (SETHIA; VON GLINOW, 1985) onde se articularam uma preocupação humanista com as pessoas e o interesse na performance, ou seja, nos resultados escolares.

No horizonte, como ideal educativo, que se traduz, também, pela obtenção de sucesso educativo, encontra-se o "nós nos educaremos". Um ideal, este de autogoverno, que se atualizou compaginando-se com o sucedâneo de circunstâncias históricas. No tempo do Estado Novo, a leitura da autonomia dos educandos compagina-se com a leitura durkheimiana (DURKHEIM, 2009), onde liberdade e autoridade se implicam e a liberdade é considerada filha da autoridade. Nesta perspetiva, fazer o que nos apetece mão significa ser livre, ao invés, ser livre é ser responsável por si próprio, é saber agir pela razão e cumprir o seu dever. Não admira por isso que a conceção de educação integral católica implique a participação ativa e voluntária do próprio dos próprios destinatários da educação. Neste aspeto vale a pena recordar a afirmação de Jean Piaget (1934), mobilizada por António Nóvoa (2005, p. 81), considerando que “[...] o self government tanto [podia] assumir a forma parlamentar e democrática (o que se chamou a democracia na escola) como reforçar o princípio dos chefes".

Finalmente, não se deve perder de vista a natureza e ação do Estado Novo no que à relação entre educação e religião diz respeito. Não sendo o Estado Novo, de todo, um estado confessional, nem por isso o regime prescindiu de mobilizar a religião católica e as suas organizaçôes como dispositivo disciplinar e pedagógico.

É relevando estas consideraçóes que analisamos o processo histórico da EMPC, entre 1930 e 1974, abordando alguns incidentes críticos (AMADO, 2013) no sentido da dilucidação da atualização de conceitos de educação, poder e ordem.

\section{Caminhos de afirmação da legitimidade política do Estado Novo no ensino normal primário}

Redução e controlo nortearam os eixos estruturantes de afirmação do poder do Estado (do Estado Novo) na política educativa, entre 1930 e 1974, especialmente no âmbito da formação de professores do ensino primário (NÓVOA, 1992).

Redução, visível no abaixamento das condiçóes da admissão ao ensino normal - de nove para seis anos de escolaridade -, e numa redução de conteúdos e dos tempos de formação. De uma formação de três anos, ampla e profissionalizante, com vinte e uma disciplinas distribuídas por quatro áreas - Ciências da Educação ou disciplinas formais do professor (e. g., Psicologia Experimental, Pedologia, Pedagogia Geral e História da Educação), Ciências ou disciplinas de aplicação ou instrutivas (e. g., Modelação e Desenho, Trabalhos Manuais), Ciências Sociais (e. 
g., História da Civilização relacionada com a História Pátria, Educação Social) e Educação Intelectual (e. g., Ciências Físico-Químicas e Naturais, Corografia de Portugal e Colónias, Língua e Literatura Portuguesas, Matemáticas Elementares, Noções de Agricultura e Economia Rural) -, passa-se para um plano de estudos, em 1942, com a duração de três semestres, reduzido a conjunto limitado de disciplinas consideradas essenciais, como se pode observar plano de estudos (quadro $n .^{\circ} 1$ ). Traduz uma menor exigência intelectual e científica que obrigará o Estado a realizar um forte investimento simbólico no sentido de salvaguardar a imagem e o prestígio dos professores, em detrimento da competência e poder profissional ou de um outro estatuto socioeconómico.

\section{Quadro 01}

\begin{tabular}{|c|c|c|c|}
\hline \multicolumn{4}{|c|}{ Plano de estudos das Escolas do Magistério Primário (1942) } \\
\hline \multirow{2}{*}{ Disciplinas } & \multicolumn{3}{|c|}{ Semestre } \\
\hline & $1^{\circ}$ & $2^{\circ}$ & $3^{\circ}$ \\
\hline Pedagogia e didáctica geral & 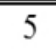 & 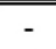 & - \\
\hline Psicologia aplicada à educação & 3 & 6 & - \\
\hline Didáctica especial & - & 6 & 6 \\
\hline Higiene escolar & 3 & - & - \\
\hline Educação fisica & 2 & 2 & 2 \\
\hline Desenho e trabalhos manuais educativos & 2 & 3 & 2 \\
\hline Educação Feminina & 2 & 2 & 2 \\
\hline Música e canto coral & 2 & 2 & 2 \\
\hline Legislação e administração escolares & - & - & 3 \\
\hline Organização politica e administrativa da Nação & 2 & - & - \\
\hline Educação moral e cívica & 2 & - & - \\
\hline Prática pedagógica & 5 & 8 & 8 \\
\hline Total & 28 & 29 & 25 \\
\hline
\end{tabular}

Fonte: Os próprios autores.

O controlo, que duraria até ao final do regime, emerge logo em 1930 e ao longo do processo de transformação completa das instituições de ensino normal. A metamorfose das Escolas Normais Primárias em Escolas do Magistério Primário não era, na perspetiva da Ditadura Nacional, uma mera questão semântica. A afirmação da legitimidade política do Estado Novo no ensino normal, consubstanciou uma mudança de atores na direçáo das escolas. Mas o processo estava ainda longe de concluído.

Em 1931 é dado mais um passo no sentido da visão técnico-didática da formação de professores, reduzindo-se a preparação intelectual dos futuros 
professores primários e acentuando o controlo moral e ideológico. Para além da desarticulaçáo formal entre a didática e a prática nas escolas de aplicação, é precarizada a situaçáo laboral dos professores do ensino normal primário, terminando com a nomeação vitalícia para a função de professor efetivo das escolas do magistério. No conjunto de medidas é, ainda, operacionalizado um novo instrumento de controlo ideológico e moral com a regulamentação dos Exames de Estado (PORTUGAL, 1931), criados um ano antes.

O Exame de Estado era composto de provas de cultura e pedagógicas. Os relatórios dos Exames de Estado acabaram por sublinhar o nível de adesão dos candidatos aos valores e propostas educativas do Estado Novo, constituindo-se num dos fatores determinantes na classificação destes. Compulsando um relatório sobre os Exames de Estado de 1934, relativo à EMPC, a apreciaçáo dos candidatos realiza-se ao nível científico, técnico e moral. Neste relatório, por exemplo, uma candidata é criticada por ser adepta da pedagogia científica e "endeusar a ciência", de apresentar relatórios que náo justificavam cabalmente os planos de aula, a par de nas aulas práticas ter revelado o perigo que corria "a escola primária portuguesa com a adoção das ideias extremistas que subordinam sem critério, o professor aos alunos" (OLIVEIRA, 1935, p. 431).

Contudo, é na apreciação moral que a crítica surge eivada da ideologia do novo poder político. Não se atendo à observação dos exames de Estado e convocando informaçóes de natureza particular para visar a Escola e alguns dos seus professores, deixa-se transparecer uma agenda ideológica. No desenvolvimento da narrativa, no relatório, considera-se o regime de coeducação e um conjunto de ideias libertárias como a causa da quebra moral dos alunos e, muito especialmente, das alunas da Escola do Magistério Primário de Coimbra (EMPC), afirmando a dado passo:

Pelo que o júri teve ocasiáo de ver e pelas informaçóes que até ele chegaram de origem particular é lícito afirmar que a moral vai num decrescendo pavoroso entre os alunos e especialmente entre as alunas que frequentam a Escola do Magistério. O regime de coeducaçãa, a tentação do convívio íntimo com os estudantes da Universidade, as liberdades da época, filhas já de ideias libertárias que pululam em certos meios, a falta de doutrinaçáo, dentro da escola, que constitua amparo e incentivo moral, o exemplo nefasto, tornado público, de determinado professor nudista - tudo tem contribuído para a baixa que já se observa e que ameaça inutilizar todos os esforços de V/ Ex. ${ }^{a}$ e dos seus cooperadores para o levantamento da escola primária portuguesa (OLIVEIRA, 1935, pp. 433-434). 
Tratou-se de uma acusação contra a EMPC e a formação de professores orientada por uma certa pedagogia científica e pelos valores e princípios da Educação Nova. Premonitoriamente, o relatório encerra destacando a necessidade de cuidar da formação moral dos alunos-mestres e das alunas-mestras, em face do perigo das ideias, contrárias às do novo Estado português, que disseminariam na regência de turmas nas escolas do país (OLIVEIRA, 1935, p. 434):

Urge voltar os olhos para a formação moral destes rapazes e destas raparigas, educadores, condutores dos homens de amanhã. Que irão eles fazer por esse Portugal além, se consigo levam apenas uma bagagem científica pretensiosa e árida, umas aspirações fantasiosas e libertárias e uns conceitos de moral que constituem um perigo para as populaçôes que lhes vão ser confiadas?

O controlo ideológico e moral prolonga-se para o quotidiano da Escola passando a incluir o recurso à exclusão. A par das perseguiçóes ideológicas e políticas ao corpo docente, previa-se agora, a expulsão dos alunos-mestres que fossem recalcitrantes à conformação moral e ideológica aos valores e princípios do novo poder político e social (PORTUGAL, 1932).

Processo que, em 1934, conheceria um episódio crucial com o desenvolvimento de uma campanha contra a EMPC, na imprensa regional - sob a epígrafe, "Onde está a escola?” -, fruto de uma denúncia inicial de um antigo aluno-mestre. A acusação dos antigos e alunos-mestres de 1934, nacionalistas e católicos, era simples, na EMPC passavam-se factos e fazia-se propaganda contra o Estado Novo - e. g. frases contra os dirigentes da nação -, e procurava-se formar os alunosmestres em valores e ideias contrárias às orientações da nova situação política - e. g., a coeducação, a escola única, o naturismo, a emancipação da mulher, a preguiça, o pacifismo. A disciplina de Didática, por exemplo, era mesmo visada por privilegiar o estrangeiro em detrimento do nacional, por discutir assuntos de natureza político-religiosa e por defender ideias contrárias às orientações do Estado Novo - e. g., ideias comunistas (MOTA, 2007, p. 220-224).

Para os antigos e para os, ainda, alunos-mestres da EMPC, conotados com as hostes nacionalistas e com a igreja, o que estava, verdadeiramente em causa, era o poder do Estado na educaçáo e a recusa liminar de qualquer resistência dentro da legalidade. Ao denunciar a escola, assumiam, estavam a cumprir um dever, dando corpo à regeneração social encetada a 28 de maio. No seu entendimento, um "governo forte" tinha o "direito e o dever de intervir na orientação educativa da nação", aspeto tanto mais relevante quando a escola primária era a única formaçáo intelectual da esmagadora maioria dos letrados portugueses. Para estes alunos-mestres a escola 
não podia nem devia ser politicamente neutra, cabendo-lhe transmitir, inculcar princípios espirituais e morais, transformando-se na "rapada oficina de almas". $\mathrm{Na}$ EMPC, como em todas as instituiçóes de ensino normal primário, os professores teriam de compenetrar-se que eram funcionários do Estado, pagos pelo Estado, deviam, por isso mesmo, colocar-se "ao serviço do progresso espiritual da Nação" e se cada um tinha a liberdade de optar pelos meios didáticos que pretendia, todos deviam "fazer convergir os seus esforços para um fim comum: o bem da nação, da pátria de todos nós” (MOTA, 2007, pp. 214-217).

A denúncia tinha como propósito a abertura de um inquérito pelo Ministro da Instrução Pública, o que veio a suceder logo nos primeiros meses de 1935. A ideia era procurar varrer da memória da formação de professores as vivências da tradição republicana de ensino normal e o espírito da Educaçáo Nova, especialmente as contrárias às orientaçốes do Estado Novo que, comprovadamente, permaneciam na escola. Em resultado, resistir passou a significar afastamento ou mesmo prisão e, no caso dos alunos-mestres, exclusão. Na verdade, um conjunto de professores foi afastado, uns da escola, outros da profissáo e, paralelamente, as matrículas no $1^{\circ}$ ano eram suspensas (TAVARES, 1935).

\section{Educação e socialização na Escola do Magistério Primário de Coimbra (1942-1974)}

Quando reabriram as matrículas no $1^{\circ}$ ano, em 1942, eram outras instituiçóes que não aqueloutras existentes aquando da suspensão das matrículas, no $1^{\circ}$ ano, seis anos antes. Agora programas, docentes e diretores concorriam para o cumprimento dos objetivos ideológicos e políticos do Estado Novo. A memória do ensino normal em Coimbra, da transição do século XIX para o XX, fora simplesmente apagada. O Estado fizera valer o seu poder e alinhara o ensino normal primário com a ordem vigente.

O plano de estudos, para além da já referenciada redução do curso para três semestres, "ganha" um conjunto de disciplinas de cariz mais ideológico, com destaque para Educação moral e cívica, com acentuada subalternização da dimensão cívica, consagrando-se uma certa orientação religiosa do ensino. Neste núcleo agregam-se, ainda, as disciplinas de Educação feminina e, à semelhança do ensino secundário, a de Organização Política e Administrativa da Nação, vulgo OPAN, onde os alunos-mestres, para além de noçôes fundamentais, nomeadamente, normas de conduta (e. g. morais, religiosas e políticas), se debruçavam sobre os elementos estruturais da nação - e. g., indivíduo, família, organismos e doutrina corporativa -, órgãos de soberania e a organização administrativa (AFONSO, 
1964). Saliente-se, ainda, que se conservaram disciplinas de cultura pedagógica, de certo modo, duplamente "expurgadas", do excessivo e do que fosse contrário às doutrinas do Estado. Tudo o que pudesse ser considerado complexo e supérfluo para a funçáo de professor do ensino primário, foi "apagado", evitandose conhecimentos que, no entender dos homens do regime, conduziriam ao pedantismo e nada acrescentariam ao eficiente desempenho docente. O professor do ensino primário não deveria saber demais. Os princípios da Educação Nova e o desejo de uma escola ativa (FERRIÈRE, 1934) estavam presentes, ainda que sem a defesa de princípios como a coeducação ou a escola única.

A análise de manuais de Pedagogia e Didática Geral, da autoria de Francisco de Sousa Loureiro, e de Didática Especial (LOUREIRO, 1950), de José Maria Gaspar (GASPAR; FERREIRA, 1944), permitem-nos captar e melhor compreender essa realidade. Confrontando-nos com manuais de pedagogia e didática, constatamos que a formação pressupõe a adesão ao regime. $\mathrm{O}$ professor, modelo de retidão moral, tem de aderir aos valores do Estado Novo. Loureiro convoca-nos, de início, para os princípios e valores que encerra a trilogia Deus, Pátria, Família, referenciando uma identidade nacional substantiva, de todos os continentes e de uma só fé, o catolicismo. Já José Maria Gaspar, num texto a quatro mãos com Orbelino Geraldes Ferreira, aponta para a finalidade nacionalista e imperial do ensino da história e geografia. E, como que retomando algumas das temáticas da polémica "Onde está a escola?”, defende a escola nacionalista em detrimento internacionalismo pedagógico e sustenta a ideia do professor funcionário, com a obrigação de servir o Estado como e nos termos que ele deseja. Os manuais encerram uma pedagogia e uma didática caldeadas nos valores do ideal católico de educação integral incorporando o muito das propostas metodológicas consubstanciadas pela Educação Nova, naturalmente despidas do projeto societal que lhe tinha estado associado até ao segundo lustro da década de 20 do século XX, traduzindo-se na recusa de todas as ideias contrárias às "orientaçôes do moderno Estado Português" (GASPAR, 1934, p. 6) - e. g., o laicismo, a coeducação ou a escola única (PINTASSILGO, 2018).

A EMPC, enquanto instituição educacional de formação, conservava um significativo grau de diferenciação das instituiçõos educativas congéneres suas contemporâneas, marca de cultura própria. Meio de transmissão de uma certa cultura escolar, a Escola do Magistério de Coimbra era também, ela própria, produtora de cultura e de identidade(s) (MAGALHÂES, 2004; SANFELICE, 2009). Como a literatura comprova, o prestígio de um cargo, a par de uma liderança forte, pode permitir aos demais atores educativos desfrutarem de um certo grau de liberdade que resulta num investimento positivo no espaço escolar (NÓVOA, 1992).

No período entre 1942 e 1974, a EMPC, aparentou sempre possuir uma liderança bicéfala, assegurada pela cumplicidade social e política de dois homens, 
Francisco de Sousa Loureiro (1909-1979) e José Maria Gaspar (1910-1987). O primeiro, diretor, o segundo, professor de Didática Especial. A legislação, só por si, já os colocava em destaque no âmbito das Escolas do Magistério Primário, o diretor, a quem competia lecionar Pedagogia e Didática Geral, o professor de Didática Especial pela importância e significado para a prática educativa e para o estágio. Licenciado em Letras, o diretor era professor efetivo do Liceu Normal D. João III, em Coimbra (1942). Reitor de diferentes liceus entre 1943 e 1946, momento em que foi nomeado diretor da Escola do Magistério Primário de Coimbra, lugar onde permaneceu até 1974 (CASTELO, 2003, p. 790791). Protagonista da construção de um ensino normal, a partir da década de quarenta, compaginado com uma educação nacionalista e católica, não se furtou ao envolvimento direto na União Nacional, tendo mesmo apresentado teses sobre educação nos congressos daquela organização. O professor Gaspar (CASTELO, 2003, p. 623-624) realizou estudos preparatórios de Filosofia e Teologia no Seminário. Diplomado pela Escola Magistério Primário em Coimbra, possuía, ainda, o curso de Ciências Pedagógicas da Faculdade Letras. Católico, nacionalista com profundas ligaçóes ao Estado Novo - e. g. presidente da Comissão Concelhia da Uniāo Nacional (UN) (Condeixa-a-Nova), secretário da Comissão Distrital de Coimbra da UN, presidente da Câmara Municipal de Condeixa-a-Nova (19481952) - e à Igreja. No campo da educação foi vogal da Junta Nacional de Educação e participou dos trabalhos da União Mundial dos Educadores Católicos. Bolseiro de Alta Cultura em Espanha (1954) e em França (1956). Autor e tradutor com percurso diversificado, expressando-se em diferentes géneros e temáticas, com colaboração assídua na imprensa, nomeadamente, de educação.

O prestígio e a liderança destes dois homens, num contexto de consenso alargado no que se refere à ideologia e aos valores educativos, criaram, aparentemente, condiçôes para o desenvolvimento de processos identitários em relação à EMPC. O exercício de um autoritarismo paternalista terá sido propício ao aparecimento de "manifestaçóes concetuais simbólicas e comportamentais que exprimem a adesão ao projeto institucional” (NÓVOA, 1992, p. 487). Nesta perspetiva, a Escola do Magistério parece ter desenvolvido uma cultura integrativa (SETHIA; VON GLINOW, 1985), compaginando uma preocupação humanista com pessoas e um interesse na performance, ou seja, nos resultados escolares (NÓVOA, 1992). A EMPC constituía uma realidade dentro de outra realidade, concitada, à escala nacional (e internacional), a uma norma política e a uma estrutura educativa, atualizando-se na relação dialética entre a liberdade e autonomia dos seus atores, na fidelidade aos seus objetivos, e a norma e a estrutura, configurando um espaço de emergência de infidelidades normativas e de construçôes identitárias (LIMA, 1998; MAGALHÁES, 2004; SANFELICE, 2009). 
A natureza da liderança do diretor ganha visibilidade através de testemunhos orais. Na relação e diálogo que estabelece com os alunos-mestres, Francisco de Sousa Loureiro adota uma postura autoritária de tom paternalista, nomeadamente a propósito de uma relação de namoro. No diálogo que mantivemos com Joaquim Grácio, antigo aluno-mestre e inspetor do ensino primário nos anos 80 do século passado, um protegido de Francisco Sousa Loureiro - chegava a orientar as aulas do próprio diretor na sua ausência (GRÁCIO, 2006) -, narra-nos a atitude de Sousa Loureiro como exemplo das cordiais relaçóes entre alunos-mestres e professores:

[...] havia uma relaçáo de amizade e solidariedade muito grande entre os próprios professores e os alunos, e mesmo entre os alunos também, inclusivamente, eu namorava a minha mulher, lembro-me que o Dr. Loureiro me chamou, duas vezes ou três:

- "Ouve lá, andas para aí com outras colegas e a Maria Eugénia a chorar pelos cantos?”, estava a ver o tipo de relaçáo que havia.

- "Vê lá pá, vê lá coitada, então ela anda para aí a chorar", - "Ó Sr. Dr. então, eu estou num curso, tenho as colegas, acabámos uma aula, há perguntas, há problemas e tal, falo com elas normalmente..."

- "Pois, mas vê lá, coitada, a Maria Eugénia é boa rapariga, [a Maria Eugénia é minha mulher] é boa rapariga, vê lá e tal...”, está a ver, isto chegava assim a este ponto de relação, não é, o que parece bastante positivo (GRÁCIO, 2006, p. 301-302).

Perante o princípio de recusa do regime de coeducação, desde que as condiçóes materiais de existência o permitissem, valha a verdade, e sabendo da vigilância apertada que era exercida sobre as alunas e os alunos-mestres no que refere às relaçóes de género - bastaria, para tanto, compulsar as páginas do Rumo -, no contexto da EMPC, e fora dele, como adiante analisaremos, é difícil não vislumbrar, para além de relaçóes amistosas e de preocupação sincera com as pessoas, uma situação de controlo e de disciplina. Relaçóes amistosas, familiares, entre corpos docente e discente, até mesmo por causa disso, parece imperar, nessa relação, a ideia de cada um no seu lugar.

Relaçôes que encerravam uma preocupação e uma atenção especial aos contextos dos rapazes e das raparigas, mesmo para além dos muros da escola, pelo menos no que isso influenciava os resultados escolares dos alunos-mestres. Uma manifestação deste posicionamento sobressai nas palavras de D. Eurico Dias Nogueira, professor de Educaçáo Moral e Cívica e futuro arcebispo de Braga 
(1977-1994), quando nos dá disso testemunho, nestes termos:

E da parte dos professores havia um interesse muito grande pelos alunos. Eu ficava admirado, eu conto-lhe um caso [...] vamos para uma reuniáo de professores e, enfim, passamos em revista os alunos todos, tinham feito exame de saída ou coisa parecida, e com surpresa, uma rapariga, que era boa aluna, caiu. [...] todos os professores, "mas esta rapariga era boa aluna", e até é mais, tinha uma bolsa de estudo e, perdia a bolsa, [...] "mas como é que é possível esta rapariga, aqui há-de haver um problema grave", e encarregamos uma das senhoras professoras, não é, de secretamente [...]: “veja lá o que é que se passa com essa rapariga" [...] passados uns dias comunica-nos: "olhem, a moça é muito pobre, veio, é filha de uma senhora viúva, mas enfim com aspiração de tirar um curso, veio da aldeia para aqui com a mãe, alugaram um quartito, umas águas furtadas para as duas, [...] e a máe cozinhava para a filha e enfim, a mãe teve um derrame cerebral, ficou inutilizada e pobre rapariga passou a ter que olhar pela mãe [...]". Ouvimos aquilo e dissemos: "bem, não vamos prejudicá-la relativamente à bolsa de estudos", e resolvemos ali dar-lhe a nota equivalente, forçar, em vez do onze dar-lhe o catorze à mesma, embora depois fosse avisada "no exame final tens as notas que mereceres, não é" [...] (NOGUEIRA, 2006, p. 249, grifo do autor).

As relaçóes nas suas dimensóes, intra e entre corpos - docente e discente - e intersubjetiva, são caldeadas, na EMPC, na ambiência católica. A situação decorre das orientaçóes do Estado compaginada com a ação de alguns atores marcando, de forma indelével, a cultura da EMPC de valores e de práticas religiosas de confissão católica. Como parecem comprovar a tendência evolutiva da disciplina Educação Moral e Cívica, os conteúdos dos manuais de Pedagogia e de Didática, a própria rotina anual de conclusão do curso, assunto a que voltaremos, as organizaçóes existentes no quotidiano da Escola - e. g., Conferências de S. Vicente de Paulo, Liga Escolar Católica ou Liga Intensificadora de Ação Missionária (LIAM) - e as práticas socioculturais existentes, tudo concorre para reconhecer na religião católica como património e repositório das ideias, sentimentos e práticas a inculcar nos alunos-mestres e nas alunas-mestras, base do consenso alargado quanto à ideologia e valores educativos. A liderança (e o prestígio) de Sousa Loureiro e José Maria Gaspar terá contribuído para o despertar, para além do mais, manifestaçóes concetuais comportamentais que traduziam a adesão ao projeto institucional. 
Resultado desta adesão, o jornal Rumo, era uma produção dos alunos e das alunas-mestras da EMPC, cuja existência está umbilicalmente ligada à liderança do professor Gaspar. A análise do periódico permitiu aceder às representações dos alunos-mestres sobre a realidade, local e nacional, incluindo sobre o quotidiano da EMPC, e adquirir uma perceção da forma como os normalistas foram educados (se apropriaram) e reproduziram o discurso do poder oficial. A formação integral exige a participação e envolvimento ativo e voluntário dos alunos e das alunasmestras (NÓVOA, 2005). A nossa leitura permitiu-nos mapear um conjunto de dimensões - Educação Nacional, Memória, Moral Católica, Mulher, Política e Quotidiano - que traduzem a ideologia e materializam as representaçóes, dos alunos-mestres da EMPC, no período do Estado Novo.

A Moral Católica emerge aí com carácter constitutivo. A religiāo católica é assumida como raiz, por contraposição a opçóes. O homem, pessoa humana dotado de alma que lhe confere o estatuto de criatura de Deus, portadora de um passado, um presente e um futuro, move-se no âmbito de um quadro de análise construído no catolicismo, referencial de valores e normas de conduta e, a partir do qual, se posiciona face ao que o rodeia e lhe impóe uma vivência quotidiana, dos conceitos à prática coletiva - da liberdade responsável à consciência individual, o amor ao próximo, passando das virtudes à natureza social do homem que determina a sua vida em família -, tudo emerge impregnado pela leitura católica. A visão conservadora e puritana, que se compulsa nas páginas do periódico, do flirt, do namoro e do matrimónio exemplificam-no. Neste contexto se compendiam o apelo a uma conduta individual de autodomínio e conformação, a defesa da doutrina da igreja face ao comunismo, racismo e nacionalismo e se mobiliza a formação social portuguesa para a defesa da tradição missionária portuguesa com orientaçáo etnocentrista - em prol da defesa de África e onde se confunde ideal cristão e a trilogia educativa do Estado Novo (MOTA, 2006, p. 392-443).

É incontornável a marca de uma vivência religiosa católica e, em alguns testemunhos orais, adivinha-se o seu caráter quase hegemónico. $\mathrm{O}$ antigo alunomestre Gonçalo Reis Torgal, foi claro ao assumir, em entrevista, a existência de uma vivência religiosa, embora considerasse que ninguém seria obrigado a rezar o terço todos os dias ou a benzer-se à entrada de cada sala. Contudo, em aparente contradiçáo, refere a promoção de práticas religiosas considerando que se incutia a prática do "status quo religioso", o ir à missa, fazer o mês de Maria, entre outros aspetos, referindo que "a própria escola fazia o mês de Maria, não é, para quem queria e ninguém era obrigado". E, como que se dando conta do poder conformador e impositivo de tais práticas, adota uma postura de equidistância e consciente da sua narrativa sobre aquela realidade, desoculta uma dimensão que não deixava de caracterizar e marcar as relaçóes e o clima da escola, destacando que "haveria talvez 
alguns que fossem por uma questão de dizer: «ó pá, se eu não vou começam a dizer que eu não vou», e iriam, pois, iriam" (TORGAL, 2006, p. 459).

Num país com 98\% de católicos, de acordo com o recenseamento de 1960. Ainda assim, um peso e um significado que se discute, face a um conjunto de critérios, como o número de casamentos canónicos, a frequência de missa e de catequese, o grau de cultura religiosa e a participaçáo nos movimentos de apostolado leigo, que parece revelar que, ainda que de forma muito desigual pelo país, a fraca participação dos católicos na vida da igreja e a fraca influência dos valores cristáos na vida das populaçóes, no período estudado (REZOLA, 1992). Contudo, é por via da vivência religiosa que a EMPC se envolve na comunidade. De acordo com Reis Torgal, a escola envolvia-se na cidade participando numa procissão, com intervençâo direta dos alunos e do seu diretor, "[...] a Escola participava na grande procissão de Corpo de Deus que era uma procissão importantíssima em Coimbra" e depois de destacar que antes da entrevista foi verificar os elementos, procurando conferir fidedignidade ao seu trabalho de rememoraçáo, afirma que "[...] o diretor era uma das pessoas chamada para levar o pálio, numa das varas" (TORGAL, 2006, p. 459).

A presença e importância da religiáo católica na formação de professores do ensino primário, em Coimbra e no país, pode ser apreciada, em termos de contributo para os princípios e valores essenciais a transmitir, em outras duas dimensóes. No contexto da EMPC, a religião católica serviu de pretexto para regulação social e as organizaçóes, a ela ligadas, foram, por vezes, mobilizadas como dispositivos disciplinares e pedagógicos, intervindo na própria vida privada de alunas e alunos-mestres. Por outro lado, por disposição legal, o ato final de conclusão do magistério primário é, do ponto de vista nacional, marcadamente religioso, contudo é possível pressentir um espaço de ação com intervenção dos destinatários dessa formação, confluindo e potenciando as orientaçóes do Estado.

Ilídio Falcáo, aluno-mestre, professor e diretor da EMPC (1977-1989), considera que, em seu entender, as organizaçóes católicas se podiam distinguir, pelo estatuto diferenciado na relação que estabeleciam com a Escola. Existiam as que atuavam "de dentro para fora" - a LEC - e as que agiam "de fora para dentro" - LIAM. Já as Conferências de S. Vicente de Paulo, feminina e masculina, "[...] funcionavam dentro da Escola" (FALCÃO, 2006, p. 126). A conferência feminina, pelo que conhecemos da sua atuação, apresenta indícios de ter funcionado como dispositivo disciplinador e pedagógico. Nas suas reunióes discutia-se a analisava-se a vida familiar também de alunas-mestras, avaliando-se as condiçóes materiais de existência da família e apreciando-se o seu comportamento e práticas. Em nome da caridade cristã atuava-se sobre comportamentos sociais condenáveis no seio da EMPC. No caso que chegou até nós, a aluna-mestra tomou conhecimento, 
reportou-a no seio familiar e foi a família que denunciou a situação. No caso vertente gerou-se um caso de exclusão, a aluna-mestra desistiu naquele ano letivo, vindo a diplomar-se um ano mais tarde. É a situação rememorizada por uma antiga aluna-mestra do período de 1961 a 1974:

[...] vinha-me embora e estou sentada ao lado de uma colega Maria de Lurdes Castelhano, nunca me esquece desta colega que vinha de Mira, uma menina muito querida, muito boa rapariguinha e, olho para o caderno que ela tem ao lado e vejo descrito a minha pessoa, sem o meu nome, ou seja, com tópicos e tinha lá reunião de São Vicente Paulo, vinha lá o meu perfil, e que eu identifiquei perfeitamente [...] (MATOS, 2006, p. 598-599).

Pela narrativa de Maria de Lurdes Matos, na reunião da Conferência tinham analisado todo o seu comportamento, dentro e fora da escola, família, namorado, etc. O problema foi desvalorizado pelo padre responsável da Conferência tendo considerado a aluna-mestra sui generis, "uma pessoa especial", enfim, "uma atleta" e que, em razão disso, tinha "um comportamento mais livre". A questão acabou por envolver diretamente o pai da aluna. Como nos explica Maria de Lurdes, a convivência com aquelas colegas, naquele momento, tornara-se insustentável: “[...] foi um ano que foi ao ar, porque os conflitos eram tantos, percebe, eu sentia-me táo mal, tão mal, eu não conseguia estar ali dentro" (MATOS, 2006, p. 600). Um acontecimento que deixa perceber uma maior complexidade e densidade no processo de socialização no âmbito da EMPC, bem como o caráter insidioso sobre a vida privada, da ação disciplinadora e conformadora de comportamentos sociais.

A cerimónia das cerimónias, nas escolas do magistério, era a Consagração ao Sagrado Coração de Maria. Cerimónia de forte carga simbólica, uma manifestação de fé à Virgem Maria, da parte dos alunos-mestres e das alunas-mestras no momento de conclusão do seu curso. A cerimónia, habitualmente precedida de um retiro e de uma missa, encerrava com a leitura da fórmula de consagraçáo (NOGUEIRA, 1960). Conheceu diferentes locais na cidade, da Capela das Carmelitas à Sé Velha, da Igreja de S. José ao ginásio da Escola do Magistério Primário de Coimbra. Por duas vezes ocorreu em Fátima, em 1952 e 1967.

$\mathrm{Na}$ década em que Fátima se constituiu, definitivamente, no altar do mundo, os alunos-mestres que compunham a direção do Rumo (A Direcção do Rumo presta homenagem àqueles que até Fevereiro táo nobremente souberam dirigir o nosso jornal Gonçalo José R. Torgal, Manuel Bernardo, Cipriano dos Santos e José Maria Nogueira, 
1953), decidem "convocar" todos os finalistas do Magistério Primário de Portugal, para se consagrarem em Fátima, numa cerimónia "já tradicional” em todas as escolas do magistério, coletiva e de "expressiva espiritualidade" (Aos finalistas do país, 1952, p. 1).

A iniciativa enquadrou a renovação dos votos pelos professores e pelas professoras (Uma ideia do rumo - aos finalistas do país, 1952), proposta que o Ministério da Educação Nacional acolheu e concedeu justificação de falta aos docentes que participassem no evento. A iniciativa envolveu, ainda, a organizaçáo de uma peregrinação, para a qual se constituiu um "numeroso grupo" (Aos finalistas do país, 1952, p. 1), partindo de Coimbra até ao santuário de Fátima, e coincidindo a chegada com a cerimónia de consagração.

O Estado por via de disposição legal, impôs princípios essenciais e fê-los ensinar. No caso vertente colabora, a par da liderança da Escola, na criação de circunstâncias favoráveis à reprodução de práticas sociais rotinadas que consubstanciam os princípios essenciais impostos, dando resposta à livre iniciativa daqueles que eram os destinatários das práticas formativas.

\section{Notas finais}

No período de institucionalização e vigência do Estado Novo, o controlo ideológico da formação e dos(as) futuros(as) professores(as) sustentado na política educativa do Estado, traduziu-se na criação de um conjunto de diapositivos na carreira docente, e.g. exames de estado, na redução da preparação técnicopedagógica, patente na redução da amplitude da formação, e.g. redução do número de disciplinas, na simplificação dos conteúdos lecionados, e.g. disciplinas de natureza psicopedagógica, bem como na introdução de um conjunto de outras disciplinas que marcadamente visavam a inculcação ideológica, e.g. OPAN.

Embora se reconheça o caráter não confessional do Estado Novo, não é menos verdade que a religião e a moral católicas configuraram valores, normas e práticas sociais no seio da EMPC. Contribuíram, de forma incisiva, para a definiçâoo de valores, ideias e sentimentos a inculcar nos futuros professores, tidoscomo exemploético-moral para todas as crianças. É neste quadro de valores e normas, de raiz católica, que pedagogicamente se promove a educação da vontade, atualizando a ideia do educar-se a si próprio, visando a conformaçáo do corpo e da alma com a participação ativa e voluntária dos próprios educandos. A par dos valores e normas, as organizaçóes católicas foram mobilizadas como dispositivos disciplinadores e pedagógicos no espaço educativo, insinuando-se ainda, quiçá muito em razão de uma liderança paternalista, pelo menos pontualmente, no espaço da vida privada e familiar do corpo discente. As práticas sociais, na EMPC, seja pela orientação supostamente católica da larga maioria do povo português, seja pelas 
opçóes de natureza político-educativa do Estado, seja pela natureza da sua liderança e, muito especialmente, pelos atores que a interpretaram, eram profundamente marcadas pelo catolicismo. De resto, como se destacaram, os próprios discursos de alunos e alunasmestras, em sede do jornal da escola, alinhavam pelo mesmo diapasão confirmando a assunção dos valores transmitidos.

Finalmente, uma nota para as relaçóes entre os corpos docente e discente, caracterizadas por amizade e familismo, eram marcadas pela ideia de cada "um no seu lugar" e em que se opacizava a hierarquia e a relação de poder entre professor(es) e aluno(s) e aluna(s)-mestra(s).

\section{Referências}

A DIRECÇÃO do Rumo presta homenagem àqueles que até Fevereiro tão nobremente souberam dirigir o nosso jornal - Gonçalo José R. Torgal, Manuel Bernardo, Cipriano dos Santos e José Maria Nogueira. Rumo, Órgáo dos alunos da Escola do Magistério Primário de Coimbra, Coimbra, ano VI, n. 64, p. 2-3, 1 de agosto de 1953.

AFONSO, A. M. Princípios fundamentais de organizaçáo política e administrativa da Naçáo: compêndio para o $3^{\circ}$ ciclo dos liceus. Lisboa: Papelaria Fernandes, 1964.

AMADO, J. (Coord.) Manual de investigaçáo qualitativa em educaçáo. Coimbra: Imprensa da Universidade de Coimbra: 2013.

AOS FINALISTAS do país. Rumo, Órgão dos alunos da Escola do Magistério Primário de Coimbra, Coimbra, ano IV, n. ${ }^{\circ}$ 23, p. 1, 15 de janeiro de 1952.

CASTELO, C. Francisco de Sousa Loureiro. In: NÓVOA, A. (Dir.). Dicionário dos Educadores Portugueses. Porto: Ediçóes ASA, 2003. p. 790-791.

CASTELO, C. José Maria Gaspar. In: NÓVOA, A. (Dir.). Dicionário dos Educadores Portugueses. Porto: Ediçóes ASA, 2003. p. 623-624.

DURKHEIM, E. Educação e Sociologia. Lisboa: Edições 70, 2009.

FALCÃO, I. Entrevista a um aluno-mestre de 1942-1960, professor nos períodos seguintes e diretor na Normalização e Anos 80. In: MOTA, L. A Escola do Magistério Primário de Coimbra (1942-1989). Entre Ideologia, Memória e História. Anexo I - Entrevistas. Tomo II. Coimbra: Faculdade de Letras/ Universidade de Coimbra, 2006. Tese de doutoramento. p. 57-141. 
FERrIÈRE, A. A Escola Activa. Porto: Educação Nacional, 1934.

GASPAR, J. M. Onde está a escola? Diário de Coimbra, Coimbra, p. 6-7, 16 de julho de 1934.

GASPAR, J. M.; FERREIRA, O. G. Notas de Didática Especial. Porto: Tip. Domingos de Oliveira, 1944.

GRÁCIO, J. M. (2006). Entrevista a um aluno-mestre no período de 19421960. In: MOTA, L. A Escola do Magistério Primário de Coimbra (19421989). Entre Ideologia, Memória e História. Anexo I - Entrevistas. Tomo II. Coimbra: Faculdade de Letras/Universidade de Coimbra, 2006. Tese de doutoramento. p. 289-317.

LIMA, L. A Escola como Organizaçáo e a Participaçáo Escolar: um estudo da escola secundária em Portugal (1974-1988). Braga: Centro de Estudos em Educação e Psicologia/Instituto de Educação e Psicologia/Universidade do Minho, 1998.

LOUREIRO, F. S. Liçóes de Pedagogia e Didática Geral. Coimbra: Livraria Gonçalves, 1950.

MAGALHÃES, J. Tecendo Nexos: história das instituições educativas. Bragança Paulista: Editora Universitária São Francisco, 2004.

MATOS, M. L. (2006). Entrevista a uma aluna-mestra no período de 1961-1974 e professora e orientadora de estágio durante as Experiências Pedagógicas. In: MOTA, L. A Escola do Magistério Primário de Coimbra (1942-1989). Entre Ideologia, Memória e História. Anexo I - Entrevistas. Tomo I. Coimbra: Faculdade de Letras/ Universidade de Coimbra, 2006. Tese de doutoramento. p. 592-651.

MOTA, L. A Escola do Magistério Primário de Coimbra (1942-1989). Entre Ideologia, Memória e História. Coimbra: Faculdade de Letras/Universidade de Coimbra. Tese de doutoramento. 2006.

MOTA, L. Confronto ideológico nos primórdios do Salazarismo: uma campanha contra a Escola do Magistério Primário de Coimbra. Estudos do Século XX, Coimbra, n.o 7, p. 205-227, 2007.

NOGUEIRA, E. D. (2006). Entrevista a um professor no período de 1942 1960. In: MOTA, L. A Escola do Magistério Primário de Coimbra (19421989). Entre Ideologia, Memória e História. Anexo I - Entrevistas. Tomo II. Coimbra: Faculdade de Letras/Universidade de Coimbra, 2006. Tese de doutoramento. p. 238-289. 
NOGUEIRA, T. Festa da Consagração do Curso de 1958-60. Rumo, Quinzenário dos alunos da Escola do Magistério Primário de Coimbra, Coimbra, ano IX, n. ${ }^{\circ} 150$, p. 1, 4, 15 de março de 1960.

NÓVOA, A. A «Educação Nacional». In: Rosas, F. (Dir.) Portugal e o Estado Novo (1930-1960). Lisboa: Editorial Presença, 1992. p. 453-519.

NÓVOA, A. Evidentemente. Histórias da Educação. Porto: ASA Editores, 2005. OLIVEIRA, F. G. Relatório da presidente de júri que funcionou na cidade de Coimbra em Maio de 1934. Boletim Oficial do Ministério de Instruçáo Pública, Ano VI, Fasc. III e IV, p. 428-435, 1935.

PINTASSILGO, J. A Escola do Magistério Primário de Lisboa durante o Estado Novo: atores, currículo, pedagogia. In: FERREIRA, N. M.; ESTRELA, A.; VALENTE, B.; COVELO, R. O Edifício da Escola Superior de Educaçáo de Lisboa: 100 anos a formar professores (1916-2016). Ciclo de Conferências. Lisboa: CIED (Centro Interdisciplinar de Estudos Educacionais)/Escola Superior de Educação/Instituto Politécnico de Lisboa, 2018. p. 77-101.

PORTUGAL. Decreto n. ${ }^{\circ}$ 20:297/1931. Diário de Governo, I Série, n. 209 , p. 2031-2033, 10 de setembro de 1931.

PORTUGAL. Decreto n. ${ }^{\circ}$ 21:695/1932. Diário do Governo, I Série, n. ${ }^{\circ} 229$, p. 1963-1970, 29 de setembro de 1932.

REZOLA, M. I. Breve panorama da situação da Igreja e da religiáo católica em Portugal (1930-1960). In: Rosas, F. (Dir.) Portugal e o Estado Novo (19301960). Lisboa: Editorial Presença, 1992. p. 222-255.

SANFELICE, J. L. História, Instituições Escolares e Gestores Educacionais. Revista HISTEDBR On-line, Campinas, n.35, p. 192-200, set.2009. Disponível em: < http://www.histedbr.fe.unicamp.br/revista/edicoes/35/art13_35.pdf>. Acesso em: 3 ag. 2018.

SETHIA, N. K.; VON GLINOW, M. A. Arriving at four cultures by managing the reward system. In: KILMANN, R. H.; SAXTON, M. J.; SERPA, R. (Ed.) Gaining control of the corporate culture. San Francisco: Jossey Bass, 1985. p. 400-421.

TAVARES, P. C. Relatório final do processo de inquérito ao funcionamento da Escola do Magistério Primário de Coimbra (30 de junho). Dossiê do Arquivo Histórico do Ministério de Educaçáo, 1935. 
TORGAL, G. R. Entrevista a um aluno-mestre no período de 1942-1960. In: MOTA, L. A Escola do Magistério Primário de Coimbra (1942-1989). Entre Ideologia, Memória e História. Anexo I - Entrevistas. Tomo II. Coimbra: Faculdade de Letras/Universidade de Coimbra, 2006. Tese de doutoramento. p. 433-502.

UMA ideia do rumo - aos finalistas do país. Rumo, Órgáo dos alunos da Escola do Magistério Primário de Coimbra, Coimbra, ano IV, n. 25, p. 1-2, 15 de fevereiro de 1952. 